\title{
Ranking Landfill Sites in Najaf Governorate, Iraq Using AHP and Fuzzy TOPSIS Methods
}

\author{
Mohammad A. Al-Anbari ${ }^{1}$, Muhannad Y. Thameer ${ }^{1}$, Nadhir Al-Ansari ${ }^{2}$ and Sven Knutsson ${ }^{2}$ \\ 1. Collage of Engineering, Babylon University, Babel 51002, Iraq \\ 2. Department of Civil Environmental and Natural Resources Engineering, Lulea University of Technology, Lulea 971 87, Sweden
}

\begin{abstract}
In Najaf Governorate, Iraq, there are five landfill sites. This study aims to rank these sites based on their criteria which are site capacity, land elevation and land price. AHP (analytic hierarchy process) method was used to weight the criteria and the technique for order preference by similarity to ideal solution. Fuzzy TOPSIS (technique for order of preference by similarity to ideal solution) method was used to rank these sites from best to worst. Based on AHP method, the site capacity criterion was the most important than land price and land elevation.
\end{abstract}

Key words: Najaf Governorate, Iraq, AHP, TOPSIS.

\section{Introduction}

Solid waste is generated in many forms by industrial, domestic, commercial and construction activities. Improper solid waste management will cause air, soil and water pollution problems particularly in third world countries where $80 \%$ of the world population lives $[1,2]$ and where the lack of financial resources is significant. $10 \%$ of each person's production life is lost as a result of waste related diseases [1]. Solid waste is increasing in tremendous amounts due to continuous population growth and increase of standard of living [3-5]. For these reasons it is of prime importance to pick the correct site that does not harm the inhabitants and the environment.

Al-Najaf Governorate is located southwest Iraq covering an area of $28,824 \mathrm{~km}^{2}$ and about 808,048 inhabitants (Fig. 1). This governorate receives about 125,817 religious tourists every year due to its importance in the Islamic world. The solid waste generated is about $122,518 \mathrm{t}$. No proper landfill site exists and for this reason proper site selection of landfill site is required. Al-Anbari et al. [6] found five

Corresponding author: Nadhir Al-Ansari, professor, research fields: water and environmental engineering. suitable sites to be used as solid waste landfills in Al-Najaf. In this research, these sites are to be evaluated.

There are hundreds proposed methods of MCDA (multicriteria decision analysis). The differences between these methods are in the theoretical background, type of questions that can be asked and types of results that are given. Some of these methods were created especially for one specific problem, and they are not helpful for other problems. AHP (analytic hierarchy process) was proposed by Saaty [7] to deal with MCDA problems probably with hierarchical structures of attributes. This method supplies a simple way to formulate a MCDA problem and to extract preference information as it only needs comparisons between problem attributes or alternatives [8]. The TOPSIS (technique for order of preference by similarity to ideal solution) was proposed by Dymova et al. [9] and Hwang and Yoon [10]. The basic idea of TOPSIS is that the best selected alternative must have the nearest distance to the positive ideal solution and on other hand, the farthest distance from the negative ideal solution [11].

In this research these methods were used to evaluate the five selected landfill sites (Fig. 2) from best to 


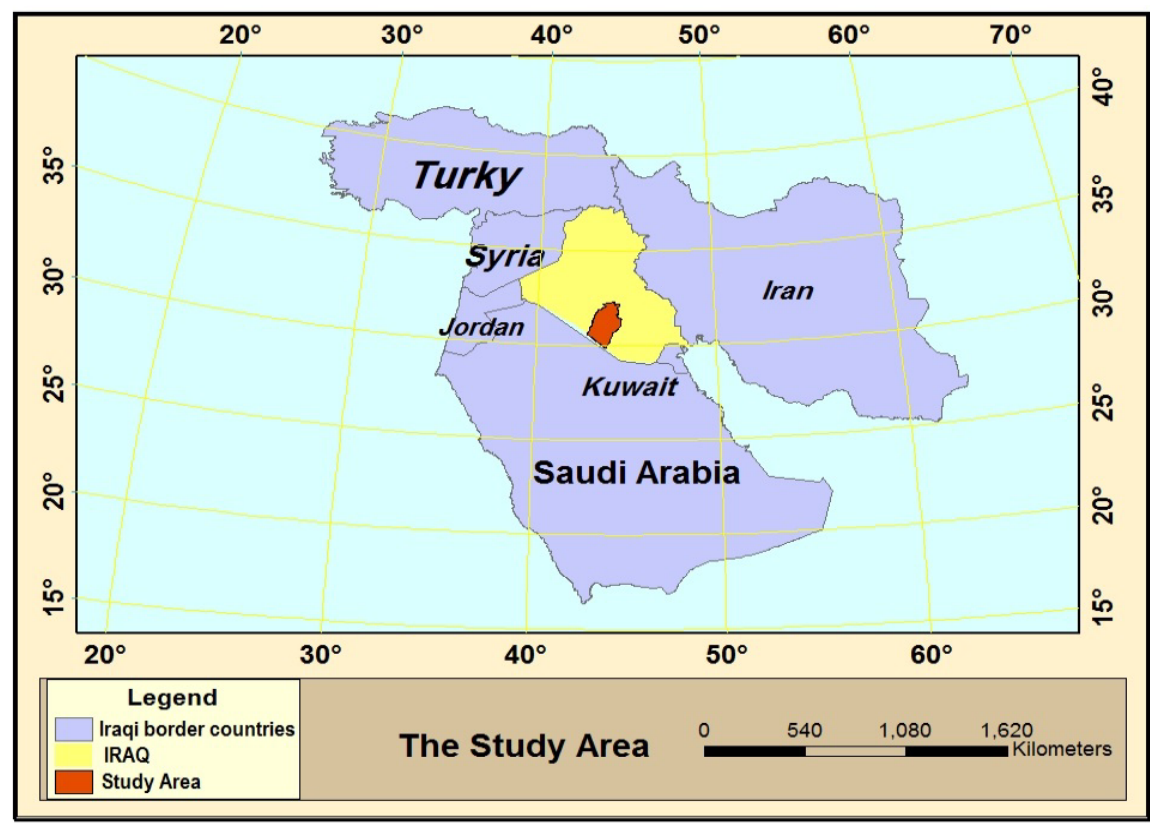

Fig. 1 Map of study area.

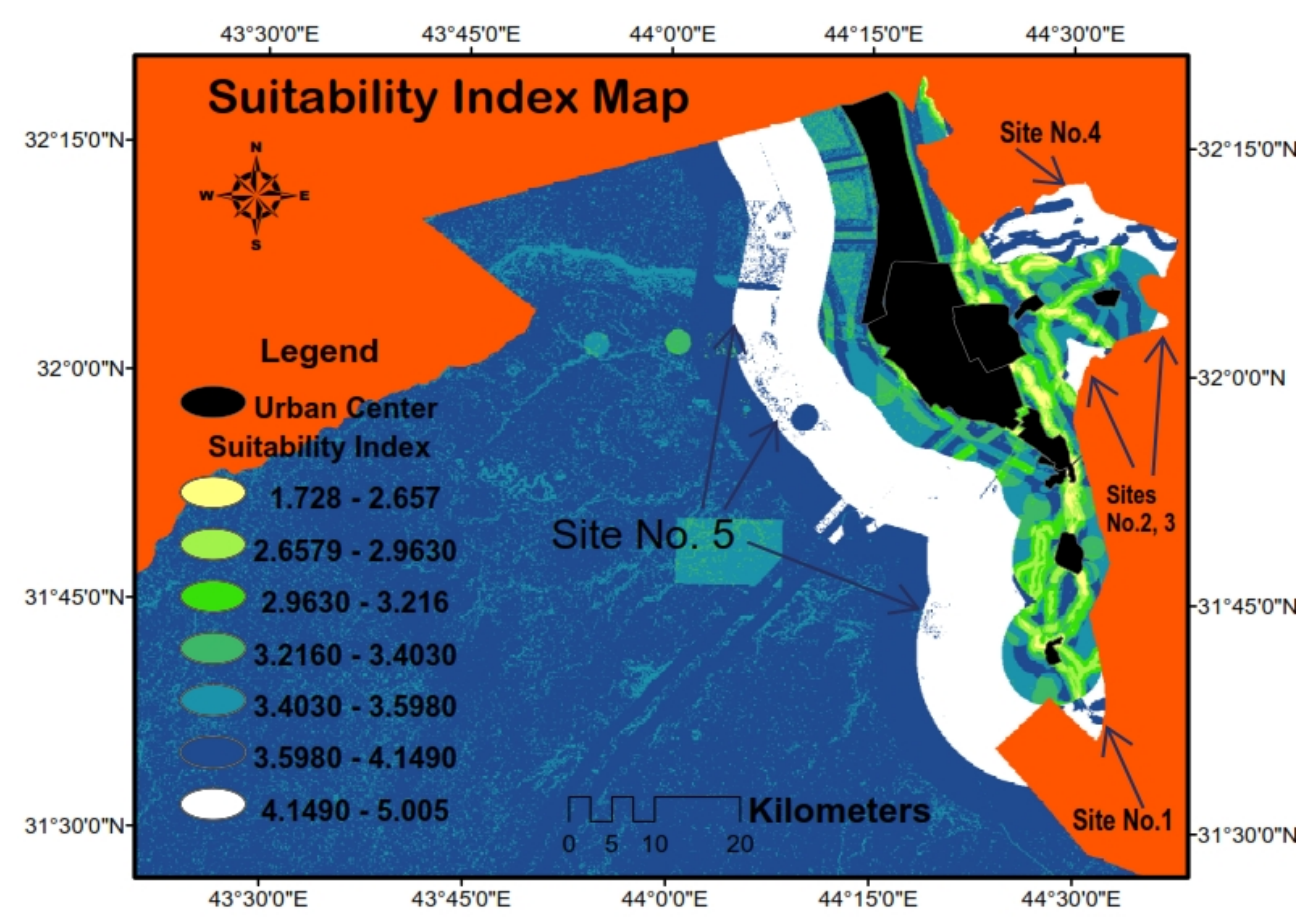

Fig. 2 Map of landfill sites.

worst according to: site capacity, land price and land elevation based on AHP and TOPSIS methods.

\section{Study Area}

Najaf Governorate lies between coordinates of latitudes $\left(32^{\circ} 21^{\prime} \mathrm{N}\right.$ and $\left.29^{\circ} 50^{\prime} \mathrm{N}\right)$, coordinates of longitudes $\left(44^{\circ} 44^{\prime} \mathrm{E}\right.$ and $\left.42^{\circ} 50^{\prime} \mathrm{E}\right)$ southwest Iraq, with a total area of $28,824 \mathrm{~km}^{2}$ (6.6\% of Iraq) (Fig. 1). Administratively, Al-Najaf Governorate includes into three qadhaas (administrative units comprising the governorate): Al-Manatheria, Al-Kufa and Al-Najaf qadaa and nine nahias (small administrative units 
comprising the qadhaa: Al-Kadissiyah, Al-Mashshkhab, Al-Hiryia, Al-Haydariya, Al-Shabaka, Al-Abbassiyah, the center of Al-Najaf qadaa, the center of Al-Kufa qadaa and the center of Al-Manatheriaqadaa). Study area is shown in Fig. 1.

\section{Application of the Methods}

This study is based on two parts. The first part is calculation of the weights of the criteria adopted by using PCM (pairwise comparison method) and the second part is ranking the sites by using TOPSIS method based on the weights that have been calculated in the first part.

\subsection{Calculating Weights for the Criteria}

Using PCM, three criteria were weighted for this study. These were site capacity, land price and land elevation (Table 1). The comparison matrix indicates the relative importance of the criterion in the columns compared to the criterion in the rows. For each comparison, the authors have to decide which of the two criteria is most important, and then assign a score to show how much important it is.

The weights for each criterion were computed as it is explained before in PCM. The resultant weights are shown in Table 2.

The consistency vector was calculated as: consistency vector (Matrix C) = weighted sum vector (Matrix A)/weights (Matrix B).The results are shown in Table 3.

The lambda $(\lambda)$ was computed as: $\lambda_{\max }=$ $(3.03534+3.01475+3.00494) / 3=3.018$.

The amount of CI (consistency index) was calculated as:

$$
\begin{gathered}
C I=(\lambda-n) /(n-1) \\
C I=(3.018-3) / 2=0.0091
\end{gathered}
$$

Then, the $C R$ (consistency ratio) was calculated as:

$$
\begin{aligned}
& C R=C I / R I(\text { random index })(\text { Table } 4) \\
& C R=0.0091 / 0.58=0.0156<0.1(\mathrm{O} . \mathrm{K})
\end{aligned}
$$

The consistency ratio calculated was 0.0156 that is

Table 1 Comparison matrix.

\begin{tabular}{llll}
\hline Criteria & SC & LP & LE \\
\hline SC & 1 & 3 & 6 \\
LP & $1 / 3$ & 1 & 3 \\
LE & $1 / 6$ & $1 / 3$ & 1 \\
\hline Total & 1.5 & 4.33 & 10 \\
\hline
\end{tabular}

*SC: site capacity; LP: land price; LE: land elevation.

Table 2 Resulting weights.

\begin{tabular}{ll}
\hline Criteria & Weight \\
\hline Site capacity & 0.652 \\
Land price & 0.25 \\
Land elevation & 0.096 \\
\hline
\end{tabular}

Table 3 Determination of the consistency vector by dividing the weighted sum vector by the criterion weights.

\begin{tabular}{lll}
\hline $\mathrm{A}$ & $\mathrm{B}$ & $\mathrm{C}$ \\
\hline 1.98205 & 0.65299 & 3.03534 \\
0.75669 & 0.25099 & 3.01475 \\
0.28850 & 0.09601 & 3.00494 \\
\hline
\end{tabular}

Table 4 Random inconsistency indices $(R I)$ for $n=1,2, \ldots, 15[12]$.

\begin{tabular}{llllll}
\hline$n$ & $R I$ & $n$ & $R I$ & $n$ & $R I$ \\
\hline 1 & 0.00 & 6 & 1.24 & 11 & 1.15 \\
2 & 0.00 & 7 & 1.32 & 12 & 1.48 \\
3 & 0.58 & 8 & 1.41 & 13 & 1.56 \\
4 & 0.90 & 9 & 1.45 & 14 & 1.57 \\
5 & 1.12 & 10 & 1.49 & 15 & 1.59 \\
\hline
\end{tabular}


less than 0.1 , indicating sufficient consistency.

\section{Criteria Analysis}

\subsection{Land Price}

The land price in the study area was divided into six grades according to the linguistic values of TOPSIS method used in this stage as shown in Table 5. The first grade means the lower price.

The price level each site from five selected sites was taken according to the estimation of Municipality Office of Najaf. Table 6 shows site categories.

\subsection{Land Elevation}

In the waste disposal process, the sea level of the area is a crucial factor. In general, when the sites are above sea level elevation, this will mean high transportation and construction costs which are considered inappropriate. On the other hand, when the elevation of the site is close to the sea level, the risk of pollution and flooding is high risk [13]. The elevation data were derived from the DEM (digital elevation model) map for the study area. The elevation for selected sites was divided into sex levels grades according to the linguistic values of TOPSIS method used in this stage (Table 5).

\subsection{Site Capacity}

In general, site should have enough capacity to allow for damping process. Ref. [14] showed that at least the site must has capacity of 10 years for dumping. AI-Bakri et al. [15] recommended 20 years life spam for the landfill to anticipate changes and expansion and five years for unfavourable sites life. Table 7 shows each site categories according to its volume.

\subsection{Sites Ranking}

By applying fuzzy TOPSIS method for ranking the sites based on the previous described three criteria, then the following steps were followed:

- Step 1: normalized fuzzy decision matrix according to Tables 6-8 (Table 9 was achieved);

- Step 2: weighted normalized fuzzy decision matrix (Table 10).

By multiplied the criteria weights in Table 2 with each element in normalized fuzzy decision matrix, the Eq. (5) is shown as follow:

where:

$$
V_{i j}=W_{i} \times r_{i j}
$$

$V_{i j}=$ weighted normalized performance value;

$W_{i}=$ weight of criteria;

$r_{i j}=$ normalized performance value;

- Step 3: distances of the ratings of each alternative from $\left(A^{\wedge} *\right)$ and $\left(A^{\wedge}-\right)$ with respect to each criterion (Table 11).

This was calculated as follows:

Table 5 Linguistic values and fuzzy numbers.

\begin{tabular}{ll}
\hline Linguistic values & Fuzzy numbers $\left(r_{i j}\right)$ \\
\hline VL (very low) & $(0,0,0.2)$ \\
$\mathrm{L}$ (low) & $(0,0.2,0.4)$ \\
$\mathrm{M}$ (medium) & $(0.2,0.4,0.6)$ \\
$\mathrm{H}$ (high) & $(0.4,0.6,0.8)$ \\
VH (very high) & $(0.6,0.8,1)$ \\
E (excellent) & $(0.8,1,1)$ \\
\hline Table 6 Linguistic values of land price for each site. & \\
\hline Site & Linguistic values \\
\hline Site 1 & $\mathrm{VL}$ \\
Site 2 & $\mathrm{H}$ \\
Site 3 & $\mathrm{M}$ \\
Site 4 & $\mathrm{M}$ \\
Site 5 & $\mathrm{~L}$ \\
\hline
\end{tabular}


Table 7 Linguistic values for site area for each site.

\begin{tabular}{llll}
\hline Site & Linguistic values & Area $\left(\mathrm{m}^{2}\right)$ & Volume $\left(\mathrm{m}^{3}\right)$ \\
\hline Site 1 & $\mathrm{M}$ & $18,942,738$ & $56,828,214$ \\
Site 2 & $\mathrm{~L}$ & $15,848,246$ & $47,544,738$ \\
Site 3 & VL & $2,944,179$ & $8,832,537$ \\
Site 4 & $\mathrm{H}$ & $123,929,845$ & $371,789,535$ \\
Site 5 & $\mathrm{E}$ & $1,130,241,351$ & $3,390,724,053$ \\
\hline
\end{tabular}

Table 8 Linguistic values for land elevation for each site.

\begin{tabular}{llll}
\hline Site & Linguistic values & Elevation range $(\mathrm{m})$ & Average $(\mathrm{m})$ \\
\hline Site 1 & L & $16 \sim 19$ & 17.5 \\
Site 2 & H & $23 \sim 27$ & 25 \\
Site 3 & H & $23 \sim 26$ & 24.5 \\
Site 4 & H & $21 \sim 23$ & 22 \\
Site 5 & VL & $16 \sim 80$ & 48 \\
\hline
\end{tabular}

Table 9 Normalized fuzzy decision matrix.

\begin{tabular}{llll}
\hline Site & SC & LP & LE \\
\hline Site 1 & $(0.2,0.4,0.6)$ & $(0,0,0.2)$ & $(0,0,0.2)$ \\
Site 2 & $(0,0.2,0.4)$ & $(0.4,0.6,0.8)$ & $(0.4,0.6,0.8)$ \\
Site 3 & $(0,0,0.2)$ & $(0.2,0.4,0.6)$ & $(0.4,0.6,0.8)$ \\
Site 4 & $(0.4,0.6,0.8)$ & $(0.2,0.4,0.6)$ & $(0.4,0.6,0.8)$ \\
Site 5 & $(0.8,1,1)$ & $(0,0.2,0.4)$ & $(0,0.2,0.4)$ \\
Weight $\left(W_{i}\right)$ & 0.653 & 0.251 & 0.096 \\
\hline
\end{tabular}

Table 10 Weighted evaluation for the alternatives.

\begin{tabular}{llll}
\hline Site & SC & LP & LE \\
\hline Site 1 & $(0.13,0.261,0.392)$ & $(0,0,0.05)$ & $(0.0,0.02,0.038)$ \\
Site 2 & $(0,0.13,0.261)$ & $(0.1,0.15,0.2)$ & $(0.038,0.057,0.076)$ \\
Site 3 & $(0,0,0.13)$ & $(0.05,0.1,0.15)$ & $(0.057,0.076,096)$ \\
Site 4 & $(0.261,0.392,0.522)$ & $(0.05,0.1,0.15)$ & $(0.038,0.057,0.076)$ \\
Site 5 & $(0.5224,0.653,0.653)$ & $(0,0.05,0.1)$ & $(0.0,0.0,0.02)$ \\
$A^{\wedge *}$ & $(1,1,1)$ & $(0,0,0)$ & $(0,0,0)$ \\
$A^{\wedge}-$ & $(0,0,0)$ & $(1,1,1)$ & $(1,1,1)$ \\
\hline
\end{tabular}

Note: $A^{\wedge} *$ means FPIS (fuzzy positive-ideal solution) for criteria and $A^{\wedge}$ - means FNIS (fuzzy negative-ideal solution).

If the criteria is cost criteria, $\left(A^{\wedge} *\right)$ is taken as $(0,0,0)$, and $\left(A^{\wedge}-\right)$ is taken as $(1,1,1)$;

If the criteria is benefit criteria, $\left(A^{\wedge} *\right)$ is taken as $(1,1,1)$, and $\left(A^{\wedge}-\right)$ is taken as $(0,0,0)$.

$$
\begin{aligned}
& \text { For benefit criteria } S^{+}=\sum_{j=1}^{n} \sqrt{\frac{1}{3}(a-1)^{\wedge} 2+(b-1)^{\wedge} 2+(c-1)^{\wedge} 2} \\
& \text { For benefit criteria } S^{-}=\sum_{j=1}^{n} \sqrt{\frac{1}{3}(a-0)^{\wedge} 2+(b-0)^{\wedge} 2+(c-0)^{\wedge} 2}
\end{aligned}
$$

and

$$
\begin{aligned}
& \text { For cost criteria } S^{+}=\sum_{j=1}^{n} \sqrt{\frac{1}{3}(a-0)^{\wedge} 2+(b-0)^{\wedge} 2+(c-0)^{\wedge} 2} \\
& \text { For cost criteria } S^{-}=\sum_{j=1}^{n} \sqrt{\frac{1}{3}(a-1)^{\wedge} 2+(b-1)^{\wedge} 2+(c-1)^{\wedge} 2}
\end{aligned}
$$


Table 11 Distances of the ratings of each alternative.

\begin{tabular}{lll}
\hline Site & $\mathrm{S}^{+}$ & $\mathrm{S}^{-}$ \\
\hline Site 1 & 0.80 & 2.24 \\
Site 2 & 1.09 & 1.962 \\
Site 3 & 1.125 & 1.918 \\
Site 4 & 0.784 & 2.249 \\
Site 5 & 0.471 & 2.556 \\
\hline
\end{tabular}

Table 12 Outranking of alternative according to fuzzy TOPSIS.

\begin{tabular}{lll}
\hline Site & $C C j$ & Rank \\
\hline Site 1 & 0.7373 & 3rd \\
Site 2 & 0.6427 & 4 th \\
Site 3 & 0.6302 & 5th \\
Site 4 & 0.7413 & 2nd \\
Site 5 & 0.8443 & 1st \\
\hline
\end{tabular}

where:

$S^{-}=$negative Euclidean distances for alternative;

$S^{+}=$positive Euclidean distances for alternative;

$n=$ number of criteria;

$(a, b, c)=$ weighted normalized performance values for alternative;

- Step 4: outranking of alternatives.

By calculating the closeness to the solution $\mathrm{CCi}$ value, the Eq. (10) is shown as follow:

$$
C C i=S^{-} /\left(S^{+}+S^{-}\right), 0 \leq C C i \leq 1
$$

where:

$C C i=$ closeness to the solution for alternative;

$S^{-}=$negative Euclidean distances for alternative;

$S^{+}=$positive Euclidean distances for alternative.

\section{Conclusions}

Five landfill sites were studied in Al-Najaf Governorate using AHP method to weight the criteria and the technique for order preference by similarity to ideal solution. Fuzzy TOPSIS method was also used to rank these sites from best to worst. The results showed that:

(1) According to the outranking of alternative according to fuzzy TOPSIS (Table 12), sanitary Landfill No. 5 is the best according to the criteria that have been adopted in this study followed by Landfills No. 4, No. 1, No. 3 and No. 2;

(2) Based on Table 2, the site capacity is considered as the most importance criteria (0.652 from 1$)$, then followed by land price, and land elevation.

\section{Acknowledgments}

The authors would like to thank all who assisted them to make this work, especially the Urban Planning Directorate in Najaf Governorate, Dr. Hussain Mousa and Engineer Hadeel Jassim.

\section{References}

[1] Pearce, D., and Walker, C. 1996. "Sustainable Development." In Water and Environmental Management in Developing Countries, edited by Baily, R. Washington, D.C.: Amazon Company.

[2] Jackson, B. 1996. "International Institutions." In Water and Environmental Management in Developing Countries, edited by Baily, R. Washington, D.C.: Amazon Company.

[3] Al-Ansari, N. A., Pusch, R., and Knutsson, S. 2013. "Suggested Landfill Sites for Hazardous Waste in Iraq." $J$. Natural Science 5 (4): 463-77.

[4] Al-Ansari, N. A., Al-Hanbali, A., and Knutsson, S. 2012. "Locating Solid Waste Landfills in Mafraq City, Jordan." J. Advance Science and Engineering Research 2 (1): 40-51.

[5] Ansari, N. A. 2013. "Locating Landfills in Arid Environment." J. Earth Sciences and Geotechnical Eng. 3 (3): $11-24$

[6] Al-Anbari, M., Thameer, M., Al-Ansari, N., and Knutsson, S. 2016. "Landfill Site Selection in Al-Najaf Governorate, Iraq." J. Civil Engineering and Architecture 10 (6): 651-60.

[7] Saaty, T. L. 1980. The Analytic Hierarchy Process. New 
York: McGraw Hill.

[8] Sen, P., and Yang, J. 1998. Multiple Criteria Decision Support in Engineering Design. London: Springer-Verlag London Limited.

[9] Dymova, L., Sevastjanov, P., and Tikhonenko, A. 2013. "An Approach to Generalization of Fuzzy TOPSIS Method." Information Sciences: An International Journal Archive 238: 149-62.

[10] Hwang, C. L., and Yoon, K. P. 1981. Multiple Attribute Decision Making: Methods and Applications. New York: Springer-Verlag.

[11] Ozturk, D., and Batuk, F. 2015, “TOPSIS (Technique for Order Prefrence by Similarity to Ideal Solution) for Spatial Decision Problems." International Society for Photogrammetry and Remote Sensing. Accessed June 1, 2016. http://www.isprs.org/proceedings/2011/Gi4DM/PD F/PP12.pdf.
[12] Şener, B. 2004. "Landfill Site Selection by Using Geographic Information Systems." M.Sc. thesis, The Graduate School of Natural and Applied Sciences of Middle East Technical University.

[13] Demesouka, O. E., Vavatsikos, A. P., and Anagnostopoulos, K. P. 2013. "Suitability Analysis for Siting MSW Landfills and Its Multicriteria Spatial Decision Support System: Method, Implementation and Case Study." Waste Management 33: 1190-206.

[14] Ekmekçioglu, M., Kaya, T., and Kahraman, C. 2010. "Fuzzy Multicriteria Disposal Method and Site Selection for Municipal Solid Waste." Waste Management 30: 1729-36.

[15] AI-Bakri, D., Shublaq, W., Kittaneh, W., and AI-Sheikh, Z. 1988. "Site Selection of a Waste Disposal Facility in Kuwait, Arabian Gulf." Waste Management \& Research 6: 363-77. 